\title{
Combined application of antagonist Bacillus amyloliquefaciens and essential oils for the control of peach postharvest diseases
}

\author{
Eva Arrebola ${ }^{a}$, Dharini Sivakumar ${ }^{\mathrm{a}, *}$, Romina Bacigalupo ${ }^{\mathrm{b}}$, Lise Korsten ${ }^{\mathrm{a}}$ \\ ${ }^{a}$ Postharvest Technology Group, Department of Microbiology and Plant Pathology, University of Pretoria, Pretoria 0002, South Africa \\ ${ }^{\mathrm{b}}$ Instituto Nacional de Tecnología Agropecuria (INTA), Estación Experimental Agropecuaria de Concordia, Entre Ríos E3200AQK, República de Argentina
}

\section{A R T I C L E I N F O}

\section{Article history:}

Received 26 May 2009

Received in revised form

3 August 2009

Accepted 4 August 2009

\section{Keywords:}

Prunus persica (L.) Batsch

Fungal pathogens

Biocontrol agent

Essential oil

\begin{abstract}
A B S T R A C T
Bacillus amyloliquefaciens РРСВ004 was selected as a potential antagonist to control Botrytis cinerea, Penicillium expansum and Rhizopus stolonifer on peach fruit. The HPLC data of PPCB004 indicated the lipopeptides iturin A, fengycin and surfactin as secondary metabolites. The GC/MS analysis of PPCB004 showed 3-hydroxy-2-butanone as the dominant compound (97.52\% of relative peak area). Thyme (TO) and lemongrass (LO) oils showed over $50 \%$ and $25 \%$ inhibition of radial mycelial growth respectively with $8 \mu \mathrm{l}$ oil per plate for all pathogens. Combination treatment with both oils failed to increase the percentage inhibition of radial mycelial growth of the pathogens. Combined application of PPCB004 with TO or LO was tested to assess the effectiveness in the control of these pathogens during postharvest storage. The biofilm formation of PPCB004 was significantly higher in LO than TO. LO (6 $\mu$ l plate $\left.{ }^{-1}\right)$ and PPCB004 completely inhibited the mycelial growth of the pathogens. Fruit inoculation trials with PPCB004 + LO in NatureFlex ${ }^{\mathrm{TM}}$ modified atmosphere packaging (MAP), showed lower disease incidence and severity at $25^{\circ} \mathrm{C}$ for $5 \mathrm{~d}$ than treatments with PPCB004 + MAP, PPCB004 + TO + MAP, LO + MAP, TO + MAP or stand-alone MAP. On naturally infected fruit, PPCB004 + LO + MAP and LO + MAP treatments retained the total soluble solids/titratable acidity ratio and flesh firmness but failed to stimulate the levels of total phenolic content, phenylalanine ammonia-lyase, $\beta$-1,3-glucanase and chitinase activities. Combination of РРСВ004 (spray treatment) + LO (in pad delivery system) in NatureFlex ${ }^{\mathrm{TM}}$ MAP showed absence of disease and off-flavour development, retained the overall appearance and increased the overall acceptance at market shelf conditions $\left(20^{\circ} \mathrm{C}\right.$ for $2 \mathrm{~d}$ ) after cold storage at $4{ }^{\circ} \mathrm{C}$ for $14 \mathrm{~d}$.
\end{abstract}

(c) 2009 Elsevier Ltd. All rights reserved.

\section{Introduction}

The major postharvest pathogens of peaches (Prunus persica (L.) Batsch.) include Botrytis cinerea Pers.:Fr. (grey mould), Penicillium expansum Link (blue mould) Rhizopus stolonifer (Ehrenb.:Fr.) (Rhizopus rot) and Monilinia spp. (Karabulut and Baykal, 2002; Zhang et al., 2007). There are three species: Monilinia fructigena, Monilinia fructicola and Monilinia laxa. The postharvest losses due to decay may increase up to $50 \%$ without fungicide treatment, although decay can be reduced to $5-10 \%$ with postharvest fungicides (Margosan et al., 1997). Because the use of synthetic fungicides is becoming more restricted due to health and environmental concerns, it is necessary to develop alternative treatments to replace these to reduce the environmental risk and satisfy consumer demands.

\footnotetext{
* Corresponding author. Tel.: +27 12 4203295; fax: +27 124204588 .

E-mail address: dharinisivakumar@yahoo.co.uk (D. Sivakumar).
}

Application of biocontrol agents Kloeckera apiculata (Karabulut and Baykal, 2002), Cryptococcus laurentii (Zhang et al., 2007) and the use of hot water brushing and Candida spp. (Karabulut et al., 2002) were researched to control postharvest diseases in peaches. According to Karabulut et al. (2002), the combination of hot water brushing and Candida spp. gave inconsistent control of postharvest decay in peaches. Bacillus spp. were considered as potential biocontrol agents due to their high spore production ability, resistance and ability to survive desiccation, heat, U.V. irradiation, and organic solvents (Romero et al., 2007). The antagonist Bacillus amyloliquefaciens RC-2 produced antifungal compounds that inhibited the conidial germination of Colletotrichum gloeosporioides in mulberry leaves. Antifungal compounds isolated from strain RC-2 were identified as iturin A, a cyclic peptide with the following sequence: Asn-Tyr-Asn-GlnPro-Asn-Ser-3-amino-tetradecanoic acid ( $\beta$-amino acid) (Yoshida et al., 2001).

The use of lemongrass oil (LO) on the control of $B$. cinerea or $R$. stolonifer was reported (Tzortzakis and Economakis, 2007). The active component of thyme oil (TO), thymol, controlled B. cinerea 
and retained the overall quality of table grapes in modified atmosphere packaging (MAP) (Valverde et al., 2005). Essential oils (EOs) and their components are gaining increasing interest due to their volatility, relatively safe status, wide acceptance by consumers, ecofriendly and biodegradable properties (Tzortzakis, 2007). Application of EOs is an attractive method to control postharvest diseases in postharvest systems due to their bioactivity in the vapour phase and the limitation of aqueous sanitation for many commodities, make them useful as possible fumigants.

Bacillus spp. (gram positive) form biofilms on fruit surfaces, which are multicellular matrixes of bacteria surrounded by extracellular polysaccharides called a glycocalyx. The glycocalyx acts as a physical barrier and is strongly anionic, thereby can protect the microcolony from external agents (Jeyasekaran et al., 2000). Recent studies suggested that the biofilm mode is important for the bacteria's ability to act as biocontrol agents (Bais et al., 2004). Monoterpene components of EO increased the biofilm formation in gram positive bacteria (Sandasi et al., 2008). Therefore, combined treatment of biocontrol agent B. amyloliquefaciens and EOs in a postharvest system may be beneficial to control the incidence of postharvest diseases during storage and transportation of peaches especially for organic growers.

The objectives of this study were to determine 1) the mode of action of the biocontrol agent $B$. amyloliquefaciens РРСВ004 against the peach postharvest pathogens $B$. cinerea; $P$. expansum; and $R$. stolonifer, 2) the antifungal activity of the EOs on peach postharvest pathogens, 3 ) the biofilm formation of $\mathrm{PPCB004}$ in presence of selected EOs, and 4) efficacy of combination treatments of PPCB004 as postharvest spray application and selected EOs in a pad delivery system in modified atmosphere packaging on disease control and disease resistance in peaches.

\section{Material and methods}

\subsection{Pathogen inoculum}

B. cinerea (Pers.:Fr.) PPRI8222, R. stolonifer (Ehrenb.:Fr.) Vuill PPRI9052 and P. expansum Link P1.1 were grown on Malt Extract Agar (MEA) (Merck, Johannesburg, South Africa) or Potato Dextrose Agar (PDA, Merck) for $7-10 \mathrm{~d}$ at $25^{\circ} \mathrm{C}$. Spore suspensions were prepared by removing the spores from the sporulating edges of the culture with a sterile glass rod by adding $5 \mathrm{ml}$ of sterile deionised water with $0.02 \%$ Tween 80 for better spore separation. Spore suspensions were filtered through double-layered cheesecloth and the spore concentration was determined by haemocytometer $\left(10^{6}\right.$ spores $\left.\mathrm{ml}^{-1}\right)$ for each fungus.

\subsection{Antagonist identification}

B. amyloliquefaciens РРСВ004 was isolated from the surface of citrus cv. 'Valencia'. Molecular identification of PPCB004 was based on colony morphology, API $50 \mathrm{CH}$ test system (BioMérieu, Marcyl'Etoile, France) and analysis of the 16S rRNA region after PCR amplification with primer 41F and 1486R-P specific for gram positive bacteria (Stackebrandt and Goodfellow, 1991). Bacterial DNA was isolated from Bacillus strains using the Illustra ${ }^{\mathrm{TM}}$ Bacterial genomicPrep Mini Spin Kit (GE-Healthcare UK Limited, Bucks, UK). For the PCR reaction, $2 \mu \mathrm{l}$ of 1:10 diluted DNA stock solution was used. The PCR products were cleaned up using the MSB Spin PCRapace Kit (Invitek, Berlin, Germany), and $3 \mu$ l of clean PCR product was used for the sequencing marker PCR by BigDye ${ }^{\circledR}$ Terminator Kit (AB Foster City, California, USA). The resulting PCR products were purified and used directly for sequencing. Homology studies were carried out using the NCBI program BLAST (Zhang et al., 2000).

\subsection{In vitro antagonistic effect of $\mathrm{B}$. amyloliquefaciens PPCB004 against the pathogens}

The antagonistic effect of PРCB004 was determined against the postharvest pathogens by the dual culture technique (Yoshida et al., 2001). The presence of antifungal secondary metabolites in the culture filtrate of PPCB004 was determined by thin layer chromatography (TLC), using the characterised Bacillus subtilis strain UMAF6614 (Romero et al., 2007) as standard. Bacterial cultures were grown in a medium optimum for lipopeptide production (Ahimou et al., 2000) at $37^{\circ} \mathrm{C}$. After $5 \mathrm{~d}$ of incubation, cells were removed by centrifuging at $2500 \mathrm{~g}$ for $10 \mathrm{~min}$ and the supernatants were extracted with $n$-butanol. Once the butanol layer was completely evaporated, the residue was dissolved in methanol for further chemical analysis. The methanolic fractions containing the secondary metabolites were analysed by TLC (Razafindralambo et al., 1993). TLC analysis of secondary metabolites was performed on TLC plates coated with Liesel gel $60 \mathrm{~F} 254,20 \mathrm{~cm} \times 20 \mathrm{~cm}$ (Merck). TLC plates were developed in chloroform/methanol/ $\mathrm{H}_{2} \mathrm{O}$ (65:25:4, v/v/v) as mobile phase. Thereafter, fungal bioautography was assayed on these TLC plates by mixing $3 \mathrm{ml}$ of fungal spore suspension in $50 \mathrm{ml}$ of autoclaved, luke-warm (ca. $50^{\circ} \mathrm{C}$ ) MEA for each pathogen. The fungal spore suspension in MEA was poured on the TLC and the plates were incubated at $25^{\circ} \mathrm{C}$ for $3-4 \mathrm{~d}$.

\subsection{Chromatography analysis of antifungal secondary metabolites and volatile compounds produced by B. amyloliquefaciens PPCB004}

The methanolic fractions used in TLC analysis were also analysed by Reverse Phase High Performance Liquid Chromatography (RP-HPLC), using an analytical reverse phase C18 column ultrasphere, 4.6-mm diam, 150-mm long (Supelco, Bellefonte, PA 16823, USA) and solutions of $0.05 \%$ trifluoroacetic acid in acetonitrile and milliQ water, with a flow rate of $1 \mathrm{ml} \mathrm{min}^{-1}$.

The identification of volatiles produced by РPСВ004 was analysed by GC/MS using a method developed by Sivakumar et al. (2008). The samples $(150 \mathrm{ml})$ were placed in a water bath at $35^{\circ} \mathrm{C}$ for $3 \mathrm{~d}$. The volatiles were isolated by purging the samples with $500 \mathrm{ml} \mathrm{N}_{2}(\mathrm{~g})$ (5.0, Afrox, Gauteng, South Africa) at $25 \mathrm{ml} \mathrm{min}^{-1}$. Multi-channel open tubular silicone rubber traps (MCTs) were used to collect the volatile compounds from the bacterial strains (Ortner and Rohwer 1996). The GC column was a Zebron, ZB1 $30 \mathrm{~m} \times 250 \mu \mathrm{m}$ ID $\times 0.25 \mu \mathrm{m}$ film thicknesses (Phenomenex, Separations, Randburg, South Africa), the velocity of the carrier gas (helium) was $46 \mathrm{~cm} \mathrm{~s}^{-1}$ $\left(1.8 \mathrm{ml} \mathrm{min}^{-1}\right)$ and the column head pressure was $65 \mathrm{kPa}$ in the constant pressure mode. The GC oven temperature program was $-20^{\circ} \mathrm{C}$ ( $3 \mathrm{~min}$ ) at $5^{\circ} \mathrm{C} \mathrm{min}^{-1}$ to $250{ }^{\circ} \mathrm{C}(5 \mathrm{~min})$. The $\mathrm{GC}$ run time was $62 \mathrm{~min}$. The $\mathrm{GC} / \mathrm{MS}$ transfer line was at $280^{\circ} \mathrm{C}$, the mass scan range was 35-450 atomic mass units in full scan mode, the source (EI+) temperature $230^{\circ} \mathrm{C}$, the MS quadruple temperature $150{ }^{\circ} \mathrm{C}$, the ionisation energy $70 \mathrm{eV}$ and the electron multiplier (EM) $1753 \mathrm{~V}$. Tentative identification of organic compounds was performed by a probability based match search of the Wiley spectral library. Matches of the mass spectra of the components to that of the library were $\geq 80 \%$. The retention times (RT) of the components were also established. Identification of each individual compound was made by comparison of their retention times with those of pure components, matching mass spectral data with those from NIST mass spectra library software.

\subsection{Antifungal activity of EOs on mycelial growth of the pathogens}

The inhibitory effects of ten EOs (Table 2) were tested in vitro on mycelial growth of $B$. cinerea, $P$. expansum and $R$. stolonifer. Preliminary screening was carried out by incorporating $10 \mu \mathrm{l}$ of 
each EO separately in $6 \mathrm{~mm}$ diameter Whatman filter discs and thereafter placing the discs in the centre of PDA plates spreadplated with $100 \mu$ l of either fungal spore suspension. The inhibitory effect of the EOs on each pathogen was determined by measuring the diameter of the inhibition zone. The two most effective EOs obtained from the preliminary screening, lemongrass (LO) and thyme oil (TO) were tested again as single or combination treatments in vitro using a disc volatilisation method, incorporating the pure EO aliquots 2, 4, 5, 6, 8 and $10 \mu \mathrm{l}$ separately in sterile Whatman filter discs (6 mm) (Plaza et al., 2004). The EO incorporated in each disc was placed on the inner surface of the Petri dish lid and the Petri dishes were sealed with Parafilm and incubated upside down at $25^{\circ} \mathrm{C}$. The inhibition zone was measured with a Vernier calliper (Digimatic; Mitutoyo Co., Japan) in $\mathrm{mm}$ and the results were expressed as percentage inhibition of radial mycelial growth (IRMG). All the assays were repeated twice with six replicates.

\subsection{Antifungal activity of EOs on spore germination of the pathogens}

Two $100 \mu \mathrm{l}$ drops of 50\% PDA were placed on sterile microscopy slides. A fungal spore suspension prepared in Ringer's solution with $0.02 \%$ Tween 80 was sprayed over the microscope slides. The slides were kept inside a sterile Petri dish at $100 \% \mathrm{RH}$, and a sterile Whatman filter disc (6 mm) incorporated with aliquots of 2, 4, 5, 6, 8 or $10 \mu \mathrm{l}$ of the two selected pure EOs was placed separately in the centre of each slide. Thereafter, the Petri dish was sealed with Parafilm and incubated at $25^{\circ} \mathrm{C}$ for $12 \mathrm{~h}$. The germination was stopped and stained with lacto-phenol cotton blue, and the stained slides were dehydrated for $30 \mathrm{~min}$ at $50^{\circ} \mathrm{C}$. The percentage spore germination was calculated by counting the number of germinated spores out of 200 spores via microscope (optical microscope Zeiss, Oberkochen, Germany) ( $40 \times$ magnification). The assay was repeated twice with six replicates.

\subsection{Effect of EO on biofilm formation of B. amyloliquefaciens PPCB004}

A liquid culture of РРСВ004 $\left(10^{8} \mathrm{cfu} \mathrm{m}^{-1}\right)$ was incubated at $37^{\circ} \mathrm{C}$ for $12 \mathrm{~h}$ to assay the biofilm formation. Biofilm formation and quantification were carried out according to Peeters et al. (2008). One hundred microlitres of PPCB004 was pipetted into the 24 wells of a microtitre plate and incubated at $37^{\circ} \mathrm{C}$ for $24 \mathrm{~h}$ to allow cell attachment and biofilm formation. For biofilm fixation, $100 \mu \mathrm{l}$ of ethanol (99\%) was added into each well of a 96-well microtitre plate. After $15 \mathrm{~min}$ the ethanol was removed and the plate was airdried. The biofilm quantification was evaluated separately in the presence of the EOs; LO or TO selected from 2.5. To assay the effect of each EO on antagonist biofilm formation, the wells of the microtitre plate fixed with PPCB004 were exposed to sterile pieces of Whatman filter paper $(80 \times 120 \mathrm{~mm})$ incorporated with aliquots of $2,4,5,6,8$ or $10 \mu \mathrm{l}$ of EO diluted in $1 \mathrm{ml}$ ethanol separately for $2 \mathrm{~h}$ and quantification of biofilms was made using a crystal violet assay. The negative controls contained biofilm and ethanol or biofilm and water. Following the incubation period, plates were washed with $100 \mu \mathrm{l}$ of sterile distilled water to remove any loosely associated or planktonic bacteria. The plates were air-dried and the wells were stained with $100 \mu \mathrm{l}$ of $0.5 \%$ crystal violet and incubated at $25^{\circ} \mathrm{C}$ for 15 min after which the plates were washed under running tap water. Finally, bound crystal violet was released by adding $150 \mu \mathrm{l}$ of $33 \%$ of acetic acid (Sigma). One hundred microlitres from each well were measured at $595 \mathrm{~nm}$ using a micro-plate reader. The mean of the samples and the standard deviations were determined and plotted against EO concentrations. The efficacy of biofilm formation was measured by comparing the readings of the biofilms at different concentrations of EOs to that of the positive and negative controls. The experiment was repeated twice with 24 replicates with each EO.

\subsection{Effect of combined treatment on the mycelial growth of pathogens}

The two EOs with the best performance (LO and TO, selected from 2.5) were used to investigate the combined effect with PPCB004 according to the volatilisation method in 2.5 with modification. A liquid culture of PРСВ004, 5\% (v/v), shake-incubated at $37^{\circ} \mathrm{C}$ for $12 \mathrm{~h}$, was added to the PDA before pouring into the Petri dishes. The inhibitory effect was measured after $5 \mathrm{~d}$ according to a $1-5$ visual scale $(1=0 \% ; 2=25 \%$ growth, $3=50 \%, 4=75 \%$, $5=100 \%$ growth).

\subsection{Effect of B. amyloliquefaciens $P P C B 004$ and $E O$} on in vivo disease development

Peach fruit, cv. Transvaal, were collected from the Morvel Boerdery packhouse, Gauteng Province, South Africa. The fruit (300) were disinfected by ethanol (70\%) spray, air-dried and thereafter wounded $(1 \times 1 \mathrm{~mm})$ with a needle. From the disinfected, wounded fruit, 150 fruits were sprayed with РРСВ004 $\left(10^{8} \mathrm{cfu} \mathrm{ml}^{-1}\right) 24 \mathrm{~h}$ prior to pathogen inoculation. Thereafter, pathogen spore suspensions $\left(10^{6}\right.$ spores $\left.\mathrm{ml}^{-1}\right)$ were sprayed on the fruit and left for $24 \mathrm{~h}$ to initiate infection. The PРСB004 and the pathogen were sprayed on the fruit surface via a pressured air sprayer for $10-15 \mathrm{~min}$. A set of ten fruit subjected to stand-alone treatments PPCB004 or LO or TO and combination treatments PPCB004 + LO or PPCB004 + TO were packed in a biodegradable modified atmosphere packaging (MAP, NatureFlex ${ }^{\mathrm{TM}}$ Biodegradable Film (E944), Innovia Films Ltd, Cumbria, UK). EO was introduced into the packaging containing the fruit by incorporating $75 \mu \mathrm{l}$ in a Whatman filter paper strip $(2 \times 5 \mathrm{~cm})$ and the packaging was heat sealed. The fruit in MAP were incubated for $3-5 \mathrm{~d}$ at $25^{\circ} \mathrm{C}$. Fruit packed in stand-alone MAP without any treatment served as control. Disease incidence was recorded and disease severity was obtained by measuring the lesion diameter ( $\mathrm{mm}$ ). Each had five replicates and each replicate contained ten fruit. The experiment was repeated twice.

\subsection{Analysis of enzyme activity and total phenolic content}

Phenylalanine ammonia-lyase (PAL) activity was determined according to Jiang et al. (2001) with some modifications. Peach pulp (10 g) obtained from five fruit per treatment (cumulative sample) was homogenised by Ultra-Turrax homogeniser (Ultra-Turrax, IKAWerk, Germany) in $15 \mathrm{ml}$ of $0.1 \mathrm{M}$ borate buffer ( $\mathrm{pH} 8.8$ ) containing $5 \mathrm{mM} \beta$-mercaptoethanol and $2 \mathrm{mM}$ EDTA. The homogenate was centrifuged for $20 \mathrm{~min}$ at $5500 \mathrm{~g}$ and the supernatant was collected and filtered using Whatman No 1 filter paper ( $55 \mathrm{~mm}$ diameter) to determine the PAL activity and total phenolic content. The PAL activity was measured by incubating $0.5 \mathrm{ml}$ supernatant with $2 \mathrm{ml}$ of $0.1 \mathrm{M}$ borate buffer ( $\mathrm{pH}$ 8.0) containing $3 \mathrm{mM}$ L-phenylalanine for $30 \mathrm{~min}$ at $37^{\circ} \mathrm{C}$. Increased absorbance at $290 \mathrm{~nm}$, due to the formation of trans-cinnamic acid, was measured spectrophotometrically. The PAL activity was expressed as change in $\mathrm{Abs}_{290} \mathrm{~h}^{-1} \mathrm{mg}^{-1}$ protein (Jiang et al., 2001). Proteins were assayed by the dye-binding method of Bradford (1976) with bovine serum albumin as the standard.

$1,3-\beta$-Glucanase ( $\beta$-Glu) activity was assayed by measuring the rate of reducing sugar production with laminarin (Sigma, USA) as the substrate (Rivera et al., 2002). Peach pulp (10 g sample) was extracted in $0.5 \mathrm{M}$ sodium acetate ( $\mathrm{pH} 5.2$ ) with $15 \mathrm{mM}$ of $\beta$-mercaptoethanol. 
The extracts were centrifuged at $5500 \mathrm{~g}$ for $30 \mathrm{~min}$ at $4{ }^{\circ} \mathrm{C}$ and the supernatants were used in $\beta$-Glu activity assay. The absorbance was measured spectrophotometrically at $660 \mathrm{~nm}$.

Chitinase activity: peach pulp (10 g) obtained from five fruit per treatment (cumulative sample) was extracted in $0.1 \mathrm{M}$ phosphate buffer ( $\mathrm{pH} 7.2$ ) with $15 \mathrm{mM}$ of $\beta$-mercaptoethanol. The extracts were centrifuged at $5500 \mathrm{~g}$ for $30 \mathrm{~min}$ at $4{ }^{\circ} \mathrm{C}$ and the supernatants were used in a chitinase assay according to Liu et al. (2003) using chitin azure (Sigma-Aldrich, Missouri USA) as substrate. The absorbance was measured spectrophotometrically at $550 \mathrm{~nm}$. For the above mentioned enzyme assays three replicate samples were taken from each treatment

Total phenolic content: determined using the Folin-Ciocalteu procedure (Jiang et al., 2001), and measured at $690 \mathrm{~nm}$ and expressed as $\mathrm{mg}$ of equivalent gallic acid $\mathrm{g}^{-1}$ fresh weight. Three replicates per treatments were used to determine the enzyme activity and the total phenolic content, and the experiment was repeated twice.

\subsection{Effect of postharvest spray application of $\mathrm{B}$. amyloliquefaciens} PPCBO04 in combination with MAP natural decay control and overall fruit quality

In the PPCB004 + MAP and PPCB004 + LO + MAP treatments, the antagonist PPCB004 $\left(10^{8} \mathrm{cfu} \mathrm{ml}^{-1}\right)$ was initially sprayed on the fruit and allowed to air dry for $1 \mathrm{~h}$. Thereafter, fruit subjected to all three treatments were packed in biodegradable NatureFlex ${ }^{\mathrm{TM}}$ packaging. For treatments that included LO, pads to release the LO within MAP during storage were made with heat sealable grade $126 / 3$ tea bag paper (Schnabel and Mercier, 2006) cut into squares $4 \mathrm{~cm} \times 5 \mathrm{~cm}$ and sealed on each side with a heat sealer. A Whatman filter paper strip $(3 \mathrm{~cm} \times 3 \mathrm{~cm})$ impregnated with $75 \mu \mathrm{l}$ LO was inserted into each tea bag and heat sealed together with the MAP containing the fruit. Fruit subjected to all four treatments were stored at $4{ }^{\circ} \mathrm{C}$ and $90 \% \mathrm{RH}$ for $14 \mathrm{~d}$. Each postharvest treatment had five replicates and each replicate consisted of ten fruit.

After cold storage, the fruit were held at $20^{\circ} \mathrm{C}$ for $48 \mathrm{~h}$ to simulate market shelf conditions and observations were made on incidence of decay, severity, fruit quality [flesh firmness, total soluble solids (TSS) and titratable acidity (TA)] and sensory parameters. Head-space gases $\mathrm{CO}_{2}$ and $\mathrm{O}_{2}$ were measured from five replicates per treatment using a PBI Dansensor $\mathrm{CO}_{2} / \mathrm{O}_{2}$ gas analyser (Checkmate 9900, Ringsted, Denmark) at the end of the $4{ }^{\circ} \mathrm{C}$ storage (14 d) and during market shelf conditions. Incidence of decay was expressed as \%decay severity measured according to surface percentage of decay score rating (score 1: $0 \%$, score $2: 25 \%$, score 3: $50 \%$, score 4: $75 \%$ and score 5: $100 \%$ ). Flesh firmness was evaluated from 10 fruit per treatment and measured on opposite sides of each fruit using a Chatillon digital penetrometer (John Chatillon \& Sons, New Cork, USA) fitted with an 8-mm fruit tester probe and expressed in Newton $(\mathrm{N})$. The TSS were determined with a digital refractometer (PR-100 Atago, Tokyo, Japan) and expressed in percentages. Percentage TA was determined by titration of juice with $0.01 \mathrm{M} \mathrm{NaOH}$ and calculated as malic acid equivalent. For sensory evaluation, ten fruit per treatment were given to a panel of ten members who are familiar with peach fruit sensory characters. The samples, coded with three-digit numericals, were presented at random one at a time. Sensory profiles were assessed using a ninecategory scale. The intensity of the descriptors increased from 1 (=none or poor) to 9 (=extreme or excellent) for aroma, flavour, taste, overall appearance (decay and skin colour) and acceptance. Overall appearance was based on decay control and skin colour retention (absence of skin browning).

\subsection{Statistical analysis}

A complete randomised design was adopted in this study. The data obtained were subjected to analysis of variance (ANOVA) using SPSS 8.0 software for Windows (SPSS Inc., Chicago, IL, USA). The mean values were compared using Tukey's HSD test at $P<0.01 \%$. The effect of LO, TO stand-alone and combination against pathogens was also analysed by a regression statistical test. For the sensory evaluation based on score rating, the means were separated using least significant difference (LSD) at $P<0.01 \%$. Limpel's formula, as described by Richer (1987), was used to determine synergistic interactions between antagonist and LO or TO. Limpel's formula is $E_{\mathrm{e}}=X+Y-(X Y / 100)$, in which $E_{\mathrm{e}}$ is the expected effect from additive response of two treatments and $X$ and $Y$ are the percentages of disease reduction relative to each agent used alone.

Table 1

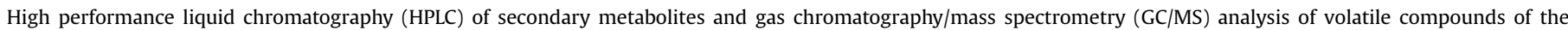
antagonist Bacillus amyloliquefaciens PPCB004.

\begin{tabular}{|c|c|c|c|c|c|c|}
\hline \multicolumn{4}{|c|}{ HPLC analysis } & \multicolumn{3}{|c|}{ GC analysis } \\
\hline $\mathrm{RT}^{\mathrm{a}}(\min )$ & $\mathrm{RPA}^{\mathrm{b}}(\%)$ & Height $(A U)^{c}$ & Product & $\mathrm{RT}$ (min) & RPA (\%) & Product \\
\hline 17.089 & 5.39 & 0.831 & Iturin A & 13.92 & 0.18 & 3-Methyl 1-butanol \\
\hline 21.742 & 2.26 & 0.366 & Iturin A & 11.88 & 97.52 & 3-Hydroxy-2-butanone (Acetoin) \\
\hline 22.527 & 2.34 & 0.402 & Iturin A & 19.41 & 0.36 & 2-Heptanone \\
\hline \multirow[t]{2}{*}{24.122} & 7.95 & 1.215 & & 26.56 & 0.42 & 2-Nonanone \\
\hline & & & & 32.86 & 0.60 & 2-Undecanone \\
\hline 40.919 & 7.57 & 0.888 & Fengycin & 34.72 & 0.12 & 2-Dodecanone \\
\hline 41.519 & 22.79 & 0.399 & Fengycin & 38.43 & 0.48 & 2-Tridecanone \\
\hline 43.848 & 5.21 & 0.550 & Fengycin & 20.88 & 0.30 & $\begin{array}{l}\text { n-(Diphenylmethylene) } \\
\text { aminoacetonitrile }\end{array}$ \\
\hline 46.671 & 1.54 & 1.777 & Fengycin & & & \\
\hline 47.437 & 5.42 & 0.343 & Fengycin & & & \\
\hline 49.359 & 4.77 & 0.278 & Fengycin & & & \\
\hline 78.825 & 2.30 & 0.372 & Surfactin & & & \\
\hline 88.251 & 12.55 & 0.579 & Surfactin & & & \\
\hline 95.075 & 15.43 & 0.458 & & & & \\
\hline 95.923 & 4.46 & 0.390 & & & & \\
\hline
\end{tabular}

a $\mathrm{RT}$ : retention time.

b RPA: relative peak area.

c AU: absorbance units. 
Therefore, if the combination of the two agents produces any value of disease reduction greater than $E_{\mathrm{e}}$, then synergism exists.

\section{Results and discussion}

\subsection{Antagonistic effect of $\mathrm{B}$. amyloliquefaciens PPCB004 on fungal pathogens}

It is evident from the dual culture, that strain PPCB004 is an efficient antagonist to inhibit the mycelial growth of $B$. cinerea (inhibition zone $31 \pm 0.28 \mathrm{~mm}), P$. expansum $(24 \pm 0.27 \mathrm{~mm})$ and $R$. stolonifer $(11 \pm 0.1 \mathrm{~mm})$. However, the non-antibiotic producer antagonist used as control failed to show any inhibitory zones. The HPLC data on the secondary metabolites of PPCB004 showed the presence of lipopeptides which were identified as iturin A, fengycin and surfactin (Table 1). The spot on TLC-bioautographies from the PPCB004 extract that showed sufficient antifungal activity to inhibit the growth of the three pathogens was identified as iturin A (Fig. 1). The antifungal effect of iturins produced by B. amyloliquefaciens has been previously shown by Yu et al. (2002). The GC/MS analysis of the volatiles produced by РPCВ004 showed 3-hydroxy2-butanone (acetoin) as the dominant compound with $97.52 \%$ of relative peak area (RPA) (Table 1). According to Choudhary et al. (2008), acetoin showed antifungal activity in a low oxygen atmosphere environment, like MAP used in this study.

\subsection{Effect of essential oils on the growth and germination of the pathogens}

The preliminary screening of the EOs mentioned in Table 2 showed different inhibitory effects on the target pathogen. B. cinerea was the most resistant pathogen. The inhibitory potency of different EOs on the three pathogens was as follows: peppermint and tea tree oils $<$ basil oils $<$ LO and TO (data not presented). Grape fruit oil showed an inhibitory effect similar to basil oil, with a $3 \mathrm{~cm}$ inhibition zone. Eucalyptus, and lemon failed to show any inhibitory effect on any of the fungal species. The LO and TO have proved their effectiveness against several postharvest pathogens (Feng and Zheng, 2007; Tzortzakis and Economakis, 2007). Therefore, LO and TO were selected for further investigation. The mode of action of the EOs is attributed to their hydrophobicity, which enables them to partition in the lipids of the cell membrane, thus disturbing its integrity and the inorganic ion equilibrium (Lambert et al., 2001).

In order to determine the most effective doses of TO and LO on the control of postharvest diseases in peaches, and to investigate their possible synergistic effect, increasing volumes of TO and LO were used in experiments. Table 3 illustrates the observed percentage of IRMG for each pathogen with the two EO treatments showing the best results, i.e. LO and TO. Significant differences $(P<0.01)$ in percentage IRMG were observed for the three tested pathogens between the stand-alone LO and TO treatments. Standalone treatment with TO showed over 50\% IRMG with $8 \mu$ oil per plate for all three pathogens but, stand-alone treatment with LO did not. The combination treatment $(\mathrm{TO}+\mathrm{LO})$ showed lower percentage IRMG $(P<0.01)$ especially for $B$. cinerea, than the standalone TO treatment, clearly showing the absence of a synergistic effect in combination treatment (LO and TO). Although all treatments completely inhibited the spore germination of $B$. cinerea, $P$. expansum and $R$. stolonifer with oil volumes of $2 \mu$ l per plate, the data from the percentage IRMG confirmed that TO showed strongest antifungal activity against the three pathogens tested in this study. The antifungal activity of EOs has been demonstrated usually using a direct contact assay such as diffusion or dilution methods (Dafarera et al., 2000; Tzortzakis and Economakis, 2007). In diffusion assays, the EO components are partitioned through the agar according to their affinity for water, and in dilution methods low water solubility has to be overcome by addition of emulsifiers or solvents such as Tween 80 or ethanol, which may alter the activity

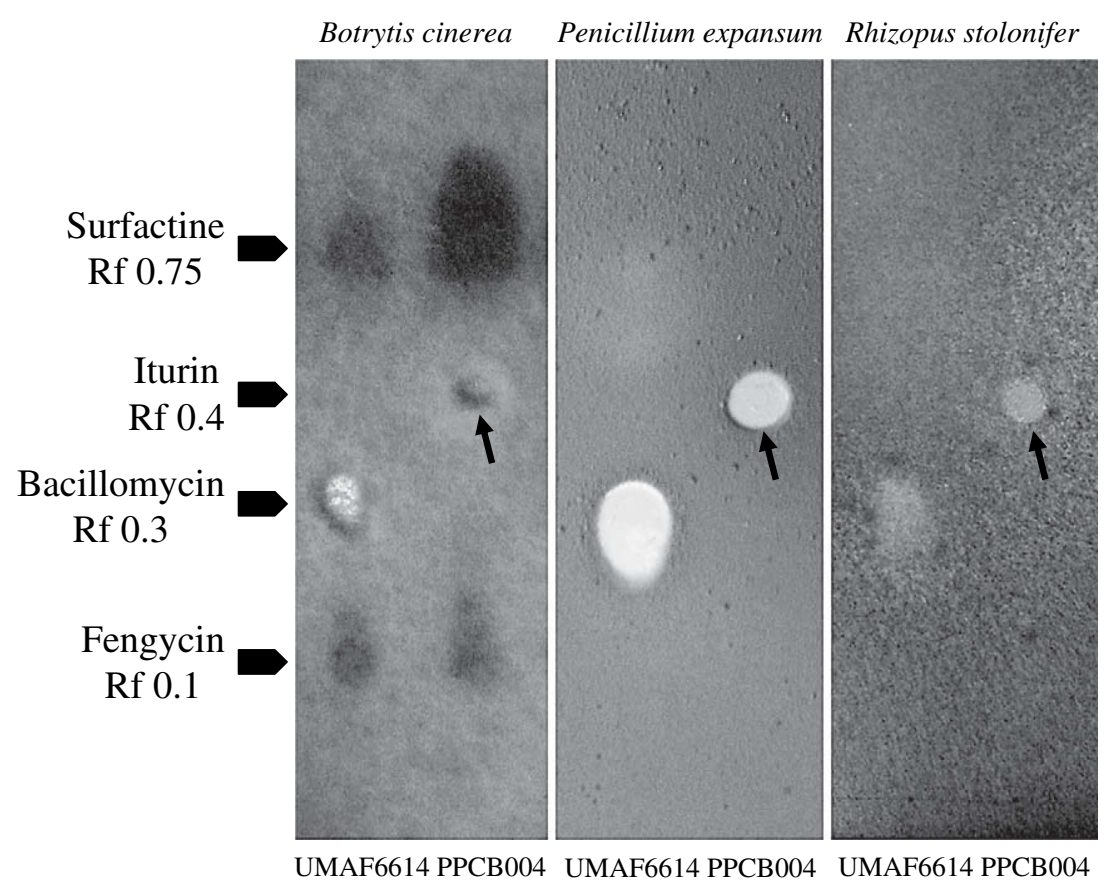

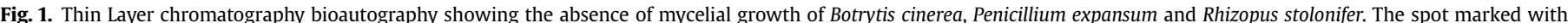

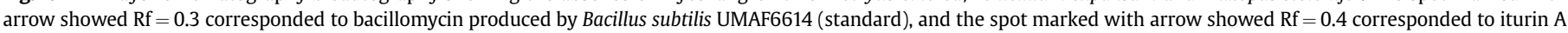
produced by Bacillus amyloliquefaciens РРСВ004. 
Table 2

List of essential oils tested in this study against Botrytis cinerea, Penicillium expansum and Rhizopus stolonifer.

\begin{tabular}{|c|c|c|c|}
\hline $\begin{array}{l}\text { Common } \\
\text { name }\end{array}$ & Botanical name & $\begin{array}{l}\text { Active } \\
\text { compound }\end{array}$ & Source $^{a}$ \\
\hline $\begin{array}{l}\text { Basil } \\
\text { Eucalyptus }\end{array}$ & $\begin{array}{l}\text { Ocimum basilicum } \mathrm{L} . \\
\text { Eucalyptus } \\
\text { melliodora } \mathrm{L} .\end{array}$ & $\begin{array}{l}\text { Estragole, linalool } \\
\text { Grandinol }\end{array}$ & $\begin{array}{l}\text { Burgess \& Finch } \\
\text { Dis-Chem }\end{array}$ \\
\hline Grapefruit & Citrus paradisi Macf. & Triclosan & Burgess \& Finch \\
\hline Lemon & Citrus limonum Risso & D-Limonene & Burgess \& Finch \\
\hline Lemongrass & $\begin{array}{l}\text { Cymbopogon } \\
\text { citratus Stapf. }\end{array}$ & Citral & Burgess \& Finch \\
\hline Peppermint & Mentha piperita $\mathrm{L}$. & Allyl isothiocyanate & Burgess \& Finch \\
\hline Tea tree & $\begin{array}{l}\text { Melaleuca } \\
\text { alternifolia } \mathrm{L} .\end{array}$ & $\alpha$-Terpinene & Dis-Chem \\
\hline Thyme & Thymus vulgaris $\mathrm{L}$. & Thymol, carvacrol & Burgess \& Finch \\
\hline
\end{tabular}

a Burgess \& Finch (Vital Health Foods S.A. Distributor, Kuils River, South Africa); Dis-Chem (Pty) Ltd. Randburg, South Africa.

of the EOs. Therefore, a disc volatilisation method was adopted in this study to identify the antifungal effect of selected EOs in a vapour phase using small volumes of EOs.

\subsection{Combined effect of B. amyloliquefaciens PPCB004 and EOs on in vitro mycelial growth and biofilm formation of $P$ PCB004}

Torres et al. (2007) showed that the combination of two or more different non-fungicidal postharvest treatments showed synergistic effects and increased their efficacy in reducing the decay development in citrus. On this basis, the synergistic effect of LO and PPCB004 or TO and PРCB004 combined treatments on radial mycelial growth of the three pathogens was tested in vitro. In the presence of PPCB004; 40\% culture plates inoculated with B. cinerea

Table 3

Effect of lemongrass or thyme oils as stand-alone or combined treatments on the percentage inhibition of radial mycelial growth of peach postharvest pathogens.

\begin{tabular}{|c|c|c|c|}
\hline Treatments & $\begin{array}{l}\text { Botrytis } \\
\text { cinerea }\end{array}$ & $\begin{array}{l}\text { Penicillium } \\
\text { expansum }\end{array}$ & $\begin{array}{l}\text { Rhizopus } \\
\text { stolonifer }\end{array}$ \\
\hline Untreated (control) & $0.00 a^{c}$ & $0.00 \mathrm{a}$ & $0.00 a$ \\
\hline $\begin{array}{l}\text { Lemongrass oil } \\
R^{2} \\
2 \mu \text { plate }^{-1} \\
4 \mu \mathrm{l} \text { plate }^{-1} \\
5 \mu \mathrm{l} \text { plate }^{-1} \\
6 \mu \mathrm{l} \text { plate }^{-1} \\
8 \mu \mathrm{l} \text { plate }^{-1} \\
10 \mu \text { plate }^{-1}\end{array}$ & $\begin{array}{c}0.82 \\
9.4 \mathrm{ab} \\
10.6 \mathrm{ab} \\
13.5 \mathrm{abc} \\
15.4 \mathrm{abc} \\
22.8 \mathrm{bcd} \\
27.8 \mathrm{bcd}\end{array}$ & $\begin{array}{l}0.80 \\
30.4 \mathrm{~b} \\
37.5 \mathrm{bc} \\
43.0 \mathrm{~cd} \\
45.3 \mathrm{~cd} \\
49.8 \mathrm{def} \\
45.1 \mathrm{~cd}\end{array}$ & $\begin{array}{l}0.84 \\
0.00 \mathrm{a} \\
29.6 \mathrm{bc} \\
26.3 \mathrm{~b} \\
30.3 \mathrm{bc} \\
34.6 \mathrm{bc} \\
43.6 \mathrm{c}\end{array}$ \\
\hline $\begin{array}{l}\text { Thyme oil } \\
R^{2} \\
2 \mu \text { plate }^{-1} \\
4 \mu \text { l plate } \\
5 \mu \text { l plate } \\
-1 \\
6 \mu \text { l plate } \\
8 \mu \text { l plate } \\
10 \mu \text { l plate } \\
10\end{array}$ & $\begin{array}{l}0.57 \\
22.9 \mathrm{bd} \\
33.5 \mathrm{de} \\
40.3 \mathrm{ef} \\
49.8 \mathrm{gf} \\
53.5 \mathrm{gf} \\
56.1 \mathrm{~g}\end{array}$ & $\begin{array}{c}0.52 \\
37.1 \mathrm{bc} \\
53.8 \mathrm{ef} \\
57.8 \mathrm{fg} \\
61.9 \mathrm{~g} \\
62.5 \mathrm{~g} \\
67.1 \mathrm{fg}\end{array}$ & \begin{tabular}{l}
\multicolumn{1}{c}{0.24} \\
64.8d \\
83.5ef \\
77.8def \\
70.9de \\
72.9def \\
78.6def
\end{tabular} \\
\hline 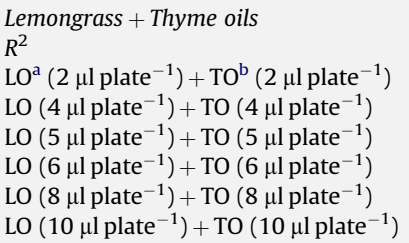 & \begin{tabular}{l}
\multicolumn{1}{c}{0.71} \\
$18.4 \mathrm{abd}$ \\
$20.0 \mathrm{abd}$ \\
$30.6 \mathrm{de}$ \\
$28.8 \mathrm{cde}$ \\
$29.1 \mathrm{cde}$ \\
$50.0 \mathrm{fg}$
\end{tabular} & $\begin{array}{l}0.57 \\
39.6 \mathrm{bc} \\
45.9 \mathrm{~cd} \\
37.5 \mathrm{bc} \\
51.6 \mathrm{de} \\
60.8 \mathrm{~g} \\
57.3 \mathrm{fg}\end{array}$ & \begin{tabular}{l}
\multicolumn{1}{c}{0.31} \\
$65.0 \mathrm{de}$ \\
80.9ef \\
76.0def \\
66.6de \\
65.4de \\
$69.7 \mathrm{de}$
\end{tabular} \\
\hline
\end{tabular}

$\mathrm{R}^{2}$ coefficients.

a LO: Lemongrass oil.

b TO: Thyme oil.

c Means followed by the same letter within columns for each pathogen are not significantly different at $P<0.01$ according to Tukey's statistic test. and $80 \%$ with $P$. expansum and $100 \%$ with $R$. stolonifer showed inhibition of mycelial growth according visual score 1 in vitro (data not presented). When LO was introduced in vitro the volume needed to show complete inhibition of mycelial growth was decreased to $6 \mu \mathrm{l}$ per plate for B. cinerea, $5 \mu \mathrm{l}$ per plate for P. expansum and $2 \mu \mathrm{l}$ per plate for $R$. stolonifer. More or less similar observations were recorded with TO; the volume of oil required to result in complete inhibition of mycelial growth was decreased to $6 \mu$ l per plate for $B$. cinerea and $2 \mu$ l per plate for $P$. expansum and $R$. stolonifer.

Due to the antimicrobial activity of EOs (Sandasi et al., 2008) it is necessary to test the effect of EO on biofilm formation of PPCB004 exposed to LO or TO. The effect of TO and LO treatments on biofilm formation is shown in Fig. 2. TO treatment significantly $(P<0.01)$ affected the biofilm formation of PРCB004, with increasing volumes of oil. However, LO treatment showed less inhibition on the biofilm formation of PPCB004 and $5 \mu \mathrm{l}$ per plate was selected as optimal volume for in vivo fruit trials. For in vivo and naturally infected fruit trials, $75 \mu \mathrm{l}$ of LO was used in an MAP postharvest system ( $75 \mu \mathrm{l}$ per MAP) which was calculated according to $5 \mu$ of LO per Petri dish.

\subsection{Effect of EO and B. amyloliquefaciens PPCB004 combined} treatment on disease incidence, enzyme activity and total phenolic content in artificially inoculated peach fruit

The observations from in vivo fruit trials showed differences $(P<0.01)$ in disease inhibition and severity between the control and treated fruits (Table 4). Combined treatment PPCB004+LO showed higher percentage of disease inhibition $(P<0.01)$ and severity reduction than $\mathrm{PPCB} 004+\mathrm{TO}$ treatment on fruit subjected to artificial inoculation with $B$. cinerea, $P$. expansum and $R$. stolonifer. The expected additive response $\left(E_{\mathrm{e}}\right)$, determined according to Limpel's formula for $B$. cinérea, P. expansum and $R$. stolonifer disease inhibition was $44 \%, 26 \%$ and $46.2 \%$ respectively in combined treatment PPCB004 + LO. The observed values of disease reduction were $50 \%$ for $B$. cinerea, $42 \%$ for $P$. expansum and $82 \%$ for $R$. stolonifer, which indicated a synergistic effect between PPCB004 and LO in inhibiting the disease incidence.

The observed effect of combined treatment PPCB004 + TO on disease inhibition and severity reduction could be due to the higher antibacterial effect of TO on the biofilm formation of PPCB004 on the fruit surface as shown in Fig. 2. The presence of phenolic rings and hydroxyl groups on the phenol rings of thymol (44.7\% of the TO fraction) and carvacrol ( $2.4 \%$ of the TO fraction), the active volatile components of TO, could have enhanced its antimicrobial activity

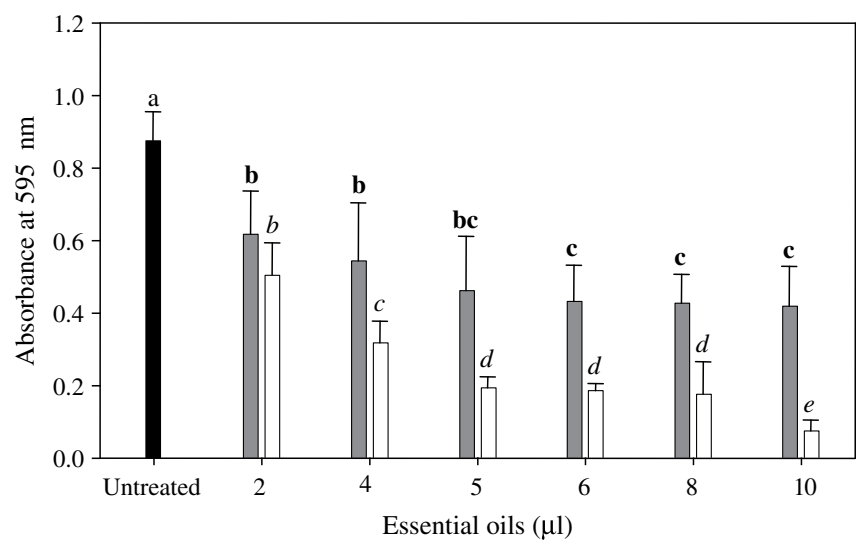

Fig. 2. Biofilm formation of Bacillus amyloliquefaciens РPСВ004 in presence of lemongrass and thyme oils at different volumes in vitro. Bars show lemongrass ( $\square$ ) and thyme $(\square)$ compared with untreated (control) ( $\square$ ) biofilm. Means in each bar followed by the same letter are not significantly different at $P<0.01$ Tukey's HSD test. 
Table 4

Percentage of disease inhibition and severity reduction in artificially infected fruit with postharvest pathogens.

\begin{tabular}{|c|c|c|c|c|c|c|}
\hline & \multicolumn{2}{|l|}{ Botrytis cinerea } & \multicolumn{2}{|l|}{ Penicillium expansum } & \multicolumn{2}{|l|}{ Rhizopus stolonifer } \\
\hline & Incidence reduction (\%) & Severity reduction (\%) & Incidence reduction (\%) & Severity reduction (\%) & Incidence reduction (\%) & Severity reduction (\%) \\
\hline Untreated (control) & $0 a^{d}$ & $0.0 \mathrm{a}$ & $2 a$ & $0.0 \mathrm{a}$ & $8 a$ & $0.0 \mathrm{a}$ \\
\hline $\mathrm{PPCBO04}^{\mathrm{a}}$ & $30 c$ & $47.6 \mathrm{c}$ & $14 \mathrm{~b}$ & $51.0 \mathrm{c}$ & $74 \mathrm{~cd}$ & $28.0 \mathrm{c}$ \\
\hline $\mathrm{LO}^{\mathrm{b}}$ & $20 \mathrm{~b}$ & $37.6 b$ & $14 \mathrm{~b}$ & $16.6 \mathrm{~b}$ & $16 b$ & $0.0 \mathrm{a}$ \\
\hline $\mathrm{TO}^{\mathrm{c}}$ & $30 c$ & $33.5 b$ & $8 a$ & $20.8 b$ & $23 b$ & $0.0 \mathrm{a}$ \\
\hline РPCВ004 + LO & $50 e$ & $44.3 c$ & $42 d$ & $58.9 d$ & $82 d$ & $40.0 d$ \\
\hline РPCВ004 + TO & $24 b$ & $27.5 \mathrm{ab}$ & $24 c$ & $51.4 \mathrm{c}$ & $74 \mathrm{~cd}$ & $14.5 b$ \\
\hline
\end{tabular}

Peach fruit cv. Transvaal were inoculated with Botrytis cinerea, Penicillium expansum or Rhizopus stolonifer separately and after $24 \mathrm{~h}$ treated with the antagonist.

The combined treatments of PPCB004 + LO and PPCB004 + TO were also evaluated against the pathogens.

a Bacillus amyloliquefaciens PPCB004.

b Lemongrass (LO).

c Thyme (TO) oils separately.

d Means followed by the same letter within columns for each pathogen for disease incidence or severity reduction are not significantly different at $P<0.01$ according to Tukey's statistic test.

(Bagamboula et al., 2004). However, in LO the active volatile component, citral (65-80\% of the LO fraction), does not have the phenolic groups in its chemical structure. Furthermore, more severe skin browning was observed in inoculated fruit treated with TO treatments. This clearly stated the phytotoxic effect of TO on the fruit, and making TO an unsuitable agent to use in combination with PPCB004. There was no significant increase in PAL activity in inoculated fruit subjected to different treatments (data not shown). However, a slight non-significant increase in PAL activity was observed in inoculated fruit subjected to TO treatments. The reason for the observed difference in PAL activity with respect to TO (stand-alone and in combination treatments) and other treatments could be due to the observed skin browning in TO treated fruit, which had resulted in stress-induced PAL activity and is not due to defence mechanisms (Cisneros-Zevallos, 2003).

No increase in total phenolic content was observed with respect to different treatments in inoculated fruit (data not presented) and $\beta$-Glu and chitinase activities were not detected in inoculated fruit subjected to these treatments (data not presented). Neither induced resistance nor production of defence enzymes seem to be involved with respect to all treatments adopted in this study. Poppe et al. (2003) reported the absence of induced resistance in citrus fruit treated with Pantoea agglomerans CPA-2 (biocontrol agent) against Penicillium digitatum and Penicillium italicum. Although LO or TO failed to show induced resistance in this study, natural volatile compounds such as methyl jasmonate have been demonstrated to enhance disease resistance responses in peaches (Jin et al., 2009). This investigation also clearly demonstrated that the antagonistic effect of PPCB004 on the three pathogens was due to the production of bacterial secondary metabolites mentioned in Table 1 the iturin A, fengycin and surfactin and also due to the volatile compounds, mainly 3-Hydroxy-2-butanone (acetoin), and biofilm formation.

\subsection{Effect of $E O$ and B. amyloliquefaciens $P P C B 004$ combination} treatments on decay incidence, fruit quality and sensory parameters of peach fruit

It is evident from this investigation that the inhibitory potency of different treatments on the postharvest decay incidence of peach fruit was as follows: PPCB004+ $\mathrm{LO}+\mathrm{MAP}>\mathrm{LO}+\mathrm{MAP}>\mathrm{PPCBO04}+\mathrm{MAP}>$ stand-alone MAP. The severity rating for naturally infected fruit subjected to the different treatments was; score $\sim 5$ for stand-alone MAP, score $\sim 2$ for PPCB004 + MAP, score $\sim 1$ for LO + MAP, score 0 for PPCB004 + LO + MAP. Flesh firmness was higher $(P<0.01)$ in fruit subjected to PPCB004 + LO + MAP and LO + MAP (Fig. 3A) treatments and at harvest the flesh firmness was $\sim 30 \mathrm{~N}$. The observed postharvest decay at market shelf conditions was the primary reason for the loss of firmness in PPCB004 + MAP and stand-alone MAP treatments. Flesh firmness was considered as the best indicator of ripening and one predictor of the potential shelf life. None of the treatments tended to increase the total phenolic content in peach fruit during storage. Tzortzakis (2007) reported different observations in tomatoes (main crop and cherry) and strawberry with respect to EO treatments and total phenolic content. In strawberry the total phenolic content was observed to decrease with EO treatments, whereas in tomatoes a non-significant increase of total phenolic content was reported. The TSS/TA at harvest was $\sim 28$. Differences $(P<0.01)$ in TSS/TA ratio were observed between the fruit subjected to PPCB004 + LO + MAP or
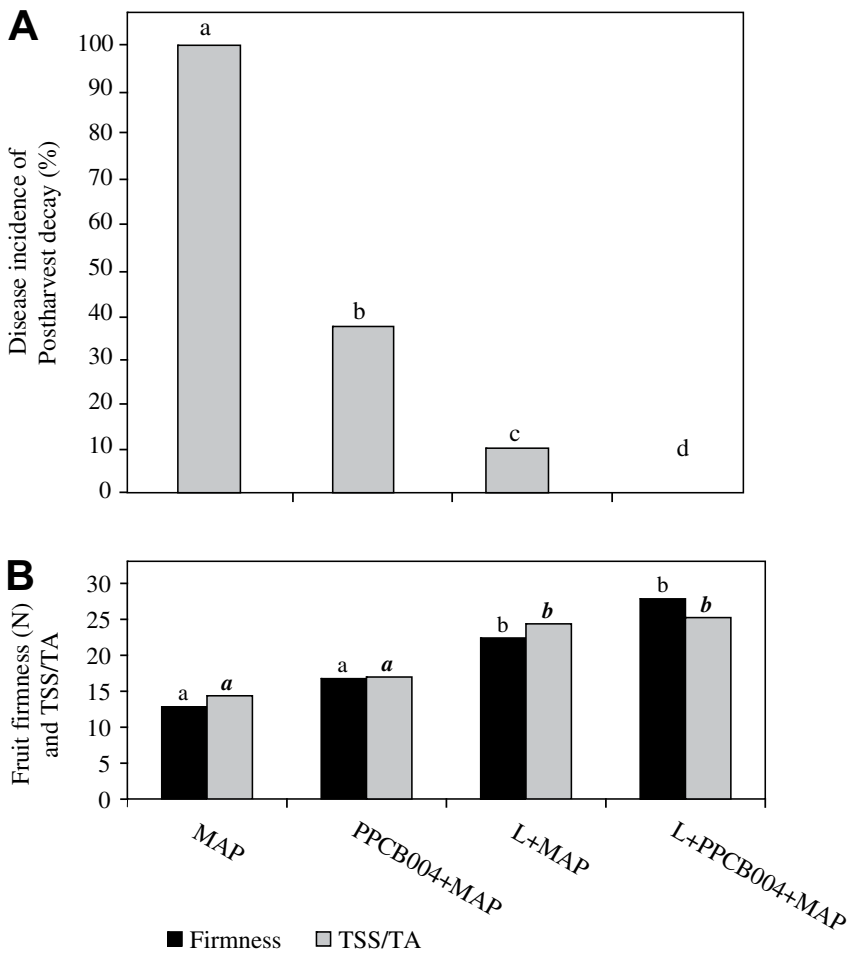

Fig. 3. Effect of postharvest treatments on (A) decay incidence of postharvest diseases (B) fruit firmness, and total soluble solid concentration/titratable acidity ratio in naturally infected peach cv Transvaal. MAP - modified atmosphere packaging (control), PPCB004 - Bacillus amyloliquefaciens LO - Lemmon grass oil. Fruit subjected to all four treatments were stored at $4{ }^{\circ} \mathrm{C}$ and $90 \% \mathrm{RH}$ for $14 \mathrm{~d}$. Means in each bar followed by the same letter are not significantly different at $P<0.01$ Tukey's HSD test. 


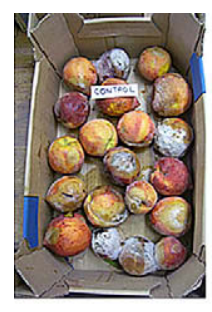

MAP

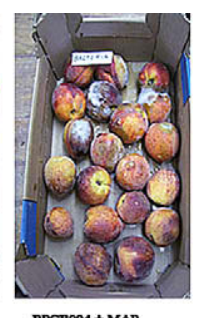

PPCB004+ MAP

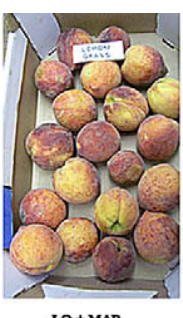

LO+ MAP

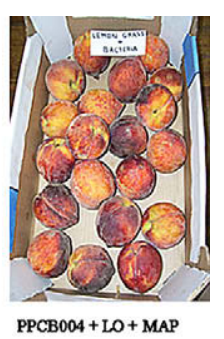

Fig. 4. Effect of postharvest treatments on overall appearance (colour and decay) of naturally infected peach cv Transvaal stored at $4{ }^{\circ} \mathrm{C}$ for $14 \mathrm{~d}$ and at $20^{\circ} \mathrm{C}$ for $2 \mathrm{~d}$. MAP modified atmosphere packaging (control), PPCB004 - Bacillus amyloliquefaciens LO lemongrass oil, TO - thyme oil.

LO + MAP and other treatments (Fig. 3B). However, stand-alone MAP and PPCB004 + MAP showed a decrease in $(P<0.01)$ TSS and increasing TA, and thereby reduced the TSS/TA ratio mainly due to the decay developed during market shelf conditions.

Sensory evaluation was not carried out for control fruit and fruit from PPCB004 + MAP due to higher decay incidence. Although the sensory panellist data revealed a similar score $(\sim 7)$ for fruit treated with $\mathrm{PPCB004}+\mathrm{LO}+\mathrm{MAP}$ and LO + MAP for taste, PPCB004 + LO + MAP treated fruit showed better overall appearance based on decay control and skin colour retention (absence of skin browning) (Fig. 4 ) and acceptance ( $\sim 8$ score). A slight odour of LO was detected immediately after opening both packages (PPCB004+LO + MAP and $\mathrm{LO}+\mathrm{MAP}$ ), but it disappeared rapidly with time due to evaporation at room temperature $\left(25^{\circ} \mathrm{C}\right)$. However, after treatment there were no adverse effects observed in aroma ( $\sim 7$ score) or flavour ( $\sim 7$ score) in either treatment as in agreement with what was observed in banana by Anthony et al. (2003).

Usage of a pad delivery system to release the LO within the MAP enabled the avoidance of tainting on the fruit in LO + MAP and PPCB004 + LO + MAP, since peaches are thin skinned and more prone to tainting as observed before with direct contact with the EO impregnated paper in the MAP in 3.4. The use of MAP has been found to be effective in retaining the overall quality in many fruit, but the $\mathrm{CO}_{2}$ concentration inside the packaging could not be increased to produce antimicrobial effects. Also, the increased $\mathrm{CO}_{2}$ concentration can result in off-flavour development in fruit. In this investigation the gas composition within the MAP was $\sim 3 \% \mathrm{O}_{2}$ and $\sim 5.0 \% \mathrm{CO}_{2}$ after cold storage and at $20^{\circ} \mathrm{C} \sim 1-1.5 \%$ increase in $\mathrm{CO}_{2}$ was observed in the MAP. The observed changes in $\mathrm{CO}_{2}$, and $\mathrm{O}_{2}$ within the packaging at $2{ }^{\circ} \mathrm{C}$ and $14{ }^{\circ} \mathrm{C}$ were due to the effect of temperature and $\mathrm{RH}$ in the storage environment on the film permeability. There tended to be slight variations in gas compositions in different postharvest treatments adopted in this study.

This investigation demonstrated that, by combining LO with the antagonist PPCB004, the fruit can be protected from the incidence of postharvest diseases and the overall fruit quality can be retained within the MAP without increasing the $\mathrm{CO}_{2}$ composition (higher than $10 \%$ ) within the packaging. EOs and their constituents are categorised as flavourings by the European Decision (2002/113/EC). Citral which is the major component of the EO fraction of LO is reported not to cause cancer in male or female rats receiving $4000 \mathrm{ppm}$ $\left(\sim 3.56 \mathrm{mg} \mathrm{ml}^{-1}\right)$ citral in the feed for 2 years (National Toxicology Program, 2003). The Acceptable Daily Intake is $5 \mathrm{mg}$ citral $\mathrm{kg}^{-1}$ body weight and it was given Generally Recognized As Safe (GRAS) status in the United States (National Toxicology Program, 2003).

The bacterial antagonist, Pseudomonas syringae Van Hall, controlled green mould of citrus and grey mould of apple, by producing an antibiotic syringomycin (Bull et al., 1998). However, the production of this antibiotic was never detected on the fruit and vegetables despite extensive efforts. The antibiotics are either produced in levels below the sensitivity for the detection methods or raise the doubt on that antibiosis is the only mechanism responsible for $P$. syringae to control postharvest disease. However, in this research the antagonist $B$. amyloliquefaciens was isolated from the surface of citrus cv. Valencia and it showed multiple modes of action in decay control. It is also evident that some stains of $B$. amyloliquefaciens do not to possess the genes encoding Bacillus enterotoxins or the key gene implicated in the synthesis of emetic toxins, or does not demonstrate phenotypic characteristic of toxin production (European Food Safety Authority, 2008). B. amyloliquefaciens and other members of the $B$. subtilis group are considered as safe and have "Generally Recognized As Safe" status, GRAS (Food and Drug Administration 1999).

\section{Conclusion}

The present study demonstrated the potential of using B. amyloliquefaciens PPCB004 in combination with LO in a pad delivery system within the biodegradable MAP. The amount of LO used in the pad delivery system was reduced by combining it with the antagonist PРСВ004 in order to reduce an unpleasant fruit odour and taste resulting from the use of LO. To our knowledge this is the first report on a combination with an antagonist and EO to improve the beneficial effect of MAP in retaining the overall fruit quality in peaches during storage. This treatment is also beneficial for organic peach growers and suitable for marketing chains of $14-16 \mathrm{~d}$.

\section{Acknowledgements}

The financial support for this research by the National Research Foundation, South Africa under a South African - Argentinian collaboration programme is greatly acknowledged. Many thanks also to Ms. C. Zeeman for editorial support and constructive suggestions.

\section{References}

Ahimou, F., Jacque, P., Deleu, M., 2000. Surfactin and iturin A effects on Bacillus subtilis surface hydrophobicity. Enzyme Microb. Technol. 27, 749-754.

Anthony, S., Abeywickrama, K., Wijeratnam, S.W., 2003. The effect of spraying essential oils of Cymbopogon nardus, Cymbopogon flexuosus and Ocimum basilicum on postharvest diseases and storage life of Embul banana. J. Hortic. Sci. Biotechnol. 78, 780-785.

Bagamboula, C.F., Uyttendaele, M., Debevere, J., 2004. Inhibitory effect of thyme and basil essential oils, carvacol, thymol, estragol, linalool and p-cymene towards Shigella sonnei and S. flexneri. Food Microbiol.. 21, 33-42.

Bais, H.P., Fall, R., Vivanco, J.M., 2004. Biocontrol of Bacillus subtilis against infection of Arabidopsis roots by Pseudomonas syringae is facilitated by biofilm formation and surfactin production. Plant Physiol. 134, 307-319.

Bradford, M.M., 1976. A rapid and sensitive method for the quantitation of microgram quantities of protein utilizing the principle of protein-dye binding. Anal .. forms of Coomassie blue G. Anal. Biochem 209, 258-266.

Bull, C.T., Wadsworth, M.L.K., Sorenson, K.N., Takemoto, J., Austin, R., Smilanick, J.L., 1998. Syringomycin E produced by biological agents controls green molds on lemons. Biol. Control 12, 89-95.

Choudhary, D.K., Johri, B.N., Prakash, A., 2008. Volatiles as priming agents that initiate plant growth and defence responses. Curr. Sci. 94, 595-604.

Cisneros-Zevallos, L., 2003. The use of controlled postharvest abiotic stresses as a tool for enhancing the nutraceutical content and adding-value of fresh fruits and vegetables. J. Food Sci. 68, 1560-1565.

Dafarera, D., Ziogas, B.N., Polissiou, M.G., 2000. GC-MS analysis of essential oils from Greek aromatic plants and their fungi toxicity on Penicillium digitatum. J. Agric. Food Chem. 48, 2576-2581.

European Food Safety Authority, 2008. Safety and efficacy of Ecobiol ${ }^{\circledR}$ (Bacillus $^{(20)}$ amyloliquefaciens) as feed additive for chickens for fattening. The EFFSA J. 773, $1-13$.

Feng, W., Zheng, X., 2007. Essential oils to control Alternaria alternata in vitro and in vivo. Food Control 18, 1126-1130.

Food and Drug Administration, 1999. Code of Federal Regulations, Title 21: Food and Drugs, Chapter 1: Food and Drug Administration Department of Health and Human Services, Part 184: Direct Food Substances Affirmed as Generally Recognized as Safe. US Government Printing Office, Washington, DC. 
Jeyasekaran, G., Karunasagar, I., Karunasagar, I., 2000. Effects of sanitizers on Listeria biofilm on contact surfaces. Asian Fish. Sci. 13, 209-213.

Jiang, Y., Joyce, D.C., Terry, L.A., 2001. 1-Methylcyclopropene treatment affects strawberry fruit decay. Postharvest Biol. Technol. 23, 227-232.

Jin, P., Zheng, Y., Tang, S., Rui, H., Wang, C., 2009. A combination of hot air and methyl jasmonate vapour treatment alleviates chilling injury of peach fruit. Postharvest Biol. Technol. 52, 24-29.

Karabulut, O.A., Baykal, N., 2002. Evaluation of the use of microwave power for the control of postharvest diseases of peaches. Postharvest Biol. Technol. 26, 237-240.

Karabulut, O.A., Cohen, L., Wiess, B., Daus, A., Lurie, S., Droby, S., 2002. Control of brown rot and blue mold of peach and nectarine by short hot water brushing and yeast antagonists. Postharvest Biol. Technol. 24, 103-111.

Lambert, R.L.W., Skandamis, P.N., Coote, P.J., Nychas, G.J.E., 2001. A study of the minimum inhibitory concentration and mode of action of oregano essential oil, thymol and carvacrol. J. Appl. Microbiol. 91, 453-462.

Liu, B.L., Kao, P.M., Tzeng, Y.M., Feng, K.C., 2003. Production of chitinase from Verticillium lecanii F091 using submerged fermentation. Enzyme Microb. Technol. 33, 410-415.

Margosan, D.A., Similanick, J.L., Henson, D.J., 1997. Combination of hot water and ethanol to control postharvest decay of peaches and nectarines. Plant Dis. 81, 1405-1409.

National Toxicology Program, 2003 Jan. NTP toxicology and carcinogenesis studies of citral (microencapsulated) (CAS No. 5392-40-5) in F344/N rats and B6C3F1 mice (feed studies). Natl. Toxicol. Program Tech. Rep. Ser. 505, 1-268.

Ortner, E.K., Rohwer, E.R., 1996. Trace analysis of semi-volatile organic air pollutants using thick film silicone rubber traps with capillary gas chromatography. J. High Resolut. Chromatogr. 19, 339.

Peeters, E., Nelis, H.J., Coenye, T., 2008. Comparison of multiple methods for quantification of microbial biofilms grown in microtiter plates. J. Microbiol. Methods 72, 157-165.

Plaza, P., Torres, R., Usall, J., Lamarca, N., Viñas, I., 2004. Evaluation of the potential of commercial post-harvest application of essential oils to control citrus decay. J. Hortic. Sci. Biotechnol. 79, 935-940.

Poppe, L., Vanhoutte, S., Höfte, M., 2003. Modes of action of Pantoea agglomerans CPA-2, an antagonist of postharvest pathogens on citrus. Eur. J. Plant Pathol. 109, 963-973.

Razafindralambo, H., Paquot, M., Hbid, C., Jacques, P., Destain, J., Thonart, P., 1993. Purification of antifungal lipopeptides by reversed-phase high performance liquid chromatography. J. Chromatogr. 639, 81-85.

Richer, D.L., 1987. Synergism: a patent view. Pestic. Sci. 19, 309-315.

Rivera, M.E., Codina, J.C., Olea, F., de Vicente, A., Pérez-García, A., 2002. Differential expression of $\beta$-1,3-glucanase in susceptible and resistant melon cultivars in response to infection by Sphaerotheca fusca. Physiol. Mol Plant Pathol. 61, 257-265.

Romero, D., de Vicente, A., Rakotoaly, R.H., Dufour, S.E., Veening, J.W., Arrebola, E., Cazorla, F.M., Kuiper, O.P., Paquot, M., Pérez-García, A., 2007. The iturin and fengycin families of lipopeptides are key factors in antagonism of Bacillus subtilis towards Podosphaera fusca. Mol. Plant Microbe Interact. 20, 430-440.

Sandasi, M., Leonard, C.M., Viljoen, A.M., 2008. The effect of five common essential oil components on Listeria monocytogenes biofilms. Food Control 19, 1070-1075.

Schnabel, G., Mercier, J., 2006. Use of a Muscodor albus pad delivery system for the management of brown rot of peach in shipping cartons. Postharvest Biol. Technol. 42, 121-123.

Sivakumar, D., Naudé, Y., Rohwer, E., Korsten, L., 2008. Volatile compounds, quality attributes, mineral composition and pericarp structure of South African litchis export cultivars Mauritius and McLean's Red. J. Sci. Food Agric. 88, 1074-1081.

Stackebrandt, E., Goodfellow, M. (Eds.), 1991. Nucleic Acids Techniques in Bacterial Systematic. Wiley, Chichester.

Torres, R., Nunes, C., Gracía, M.J., Abadias, M., Viñas, I., Manso, T., Olmo, M., Usall, J., 2007. Application of Pantoea agglomerans CPA-2 in combination with heated sodium bicarbonate solutions to control the major postharvest diseases affecting citrus at several Mediterranean locations. Eur. J. Plant Pathol. 118, 73-83.

Tzortzakis, N.G., 2007. Maintaining postharvest quality of fresh produce with volatile compounds. Innov. Food Sci. Emerg. Technol. 8, 111-116.

Tzortzakis, N.G., Economakis, C.D., 2007. Antifungal activity of lemongrass (Cymbopogon citrates L.) essential oil against key postharvest pathogens. Innov. Food Sci. Emerg. Technol. 8, 253-258.

Valverde, J.M., Guillen, F., Martinez-Romero, D., Castillo, S., Serrano, M., Valero, D., 2005. Improvement of table grapes quality and safety by the combination of modified atmosphere packaging (MAP) and eugenol, menthol, or thymol. J. Agric. Food Chem. 53 (19), 7458-7464.

Yoshida, S., Hiradate, S., Tsukamoto, T., Hatakeda, K., Shirata, A., 2001. Antimicrobial activity of culture filtrate of Bacillus amyloliquefaciens RC-2 isolated from mulberry leaves. Phytopathology 91, 181-187.

Yu, G.Y., Sinclair, J.B., Hartman, G.L., Bertagnolli, B.L., 2002. Production of iturin A by Bacillus amyloliquefaciens suppressing Rhizoctonia solani. Soil Biol. Biochem. 34, 955-963.

Zhang, H., Zheng, X., Yu, T., 2007. Biological control of postharvest disease of peach with Cryptococcus laurentii. Food Control 18, 287-291.

Zhang, Z., Schwart, S., Wagner, L., Miller, W., 2000. A greedy algorithm for aligning DNA sequences. J. Comput. Biol. 7, 203-214. 